\title{
CORRELATION OF RADIONUCLIDE LEACHABILITIES WITH MICROSTRUCTURES OF GLASSES CONTAINING SAVANNAH RIVER PLANT WASTE
}

J. A. KELLEY

W. N. RANKIN
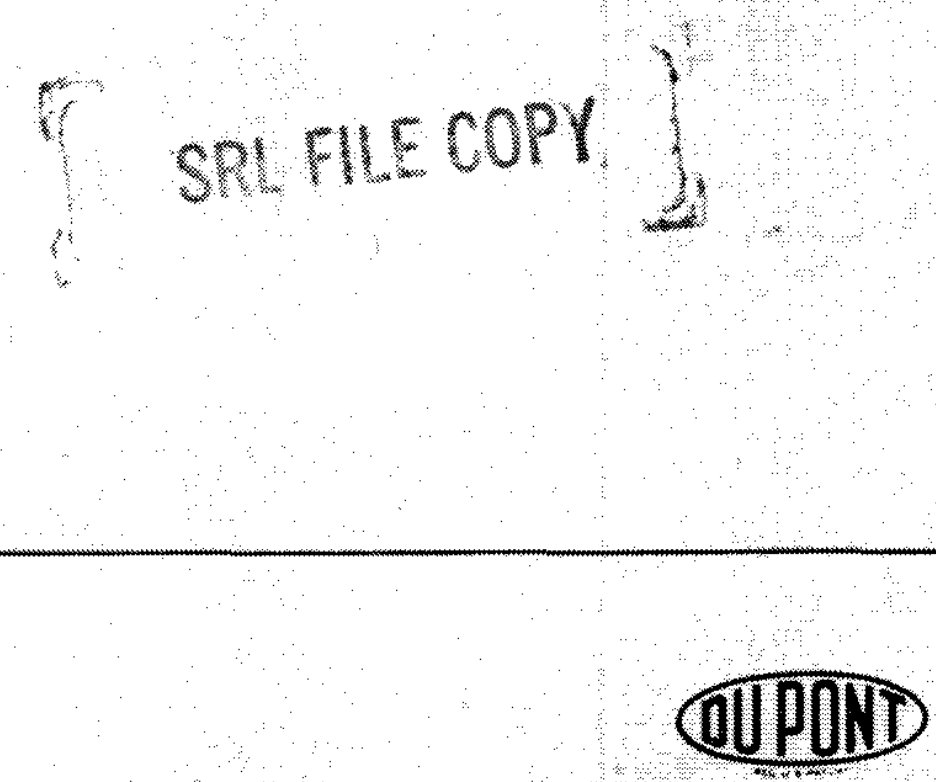

SAVANNAH RIVER LABORATORY AIKEN, SOUTH CAROLINA 29801 


\section{NoricE}

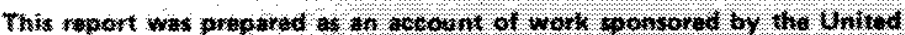

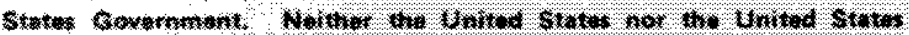

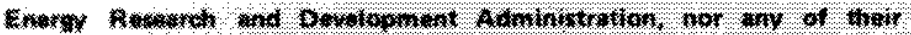

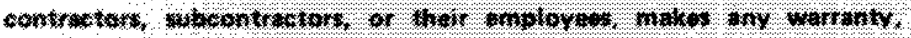

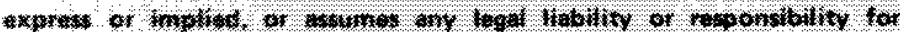

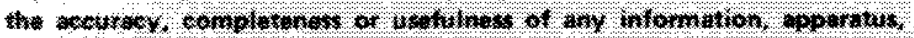

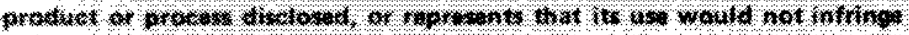

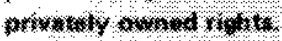

Ninted in Uhitod States of Amariea Avatubrowom

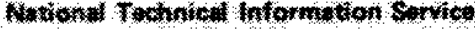

U. Soppertment of Commeres W285 Port hoy how sornthed, Vorinin 22161

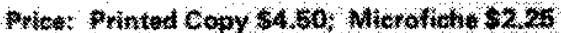




\section{CORRELATION OF RADIONUCLIDE LEACHABILITIES \\ WITH MICROSTRUCTURES OF GLASSES CONTAINING SAVANNAH RIVER PLANT WASTE}

by

3. A. KLLEY

W. N. AANKIN

Approved by

W. Hale, Jr., Research Manager

Separations Chemistry Division

R. T. Huthoon, Research Manager

Nuclear Materials Division

publication Date: May 1976

E. 1. DUPONT DE NEMOURS ANO COMPANY

SAVANNAH RIVER LABORATORY

AIKEN, SOUTH CAROLINA $2980 ?$

PRE 


\section{ABSTRACT}

Leachabilities of cesium and strontium from the glass matrices were correlated with the microstructures of glasses containing waste sludge from two SRP waste tanks. All sludge components, except mercury which volatilized, were completely soluble in the melt, but small amounts of crystalline iron oxide precipitated during cooling. These precipitates were less leachable than the glass matrix. Even though the compositions of the two sludges that were tested were similar, glass containing one of the sludges devitrified during heating at $600^{\circ} \mathrm{C}$; glass containing the other sludge did not devitrify. Leachability of the devitrified glass was as much as 100 times greater than that of nondevitrified glass, but still very low, $<10^{*} \mathrm{~g} /\left(\mathrm{cm}^{2}\right)($ day $)$. 
CONTENTS

introduction 5

Description of SRP Waste 6

Gasses Contaning Actual SRP Sludge 7

kesults of leach Tests 8

Gasses Containing Simulated sudges 9

Microstructures of Glasses Containing Actual Sludges 9

X ray Anayses of Glasses Containing Actual Sludges 11

Conclusions and Future Work 14

Refereaces 15 


\section{LIST OF FIOURES}

1 Microstructure of Glass $18-40-13 \quad 10$

2 Merostructure of Glass $18-40 m 5 \quad 12$

3 Nerostructure of Glass $18 \mathrm{~m} 30 \mathrm{~m} 13 / \mathrm{z} \quad 13$

\section{LIST OF TABLES}

1 Composition of Glass frit (Glass Mix 18) 5

2 Cheminal Composition of Washed, Dried Sludges 6

3 Radionuclides in Washed, Dried Sludges 7

4 Comparison of leachabilities of Heated and Unheated Waste classes 8 


\section{CORRELATION OF RADIONUCLIDE LEACHABILITIES WITH MICROSTRUCTURES OF GLASSES CONTAINING SAVANNAH RIVER PLANT WASTE}

\section{INTRODUCTION}

Glass is being studied as a possible matxix for long-term stowage of Savarnah River plant (SRP) high-level waste. 12 Properties of glass that make it attractive for this purpose are its low leachability and high strength.

Previous studies ${ }^{12}$ identified an acceptable glass composim tion, designated Glass Mix 18 (Table 1), that allowed incoxporation of 25 to 40 wt 8 SR waste sludge into high quality waste foms. Those studies also included measurements of volatility of radiom nuclides during melting and of leachabilities of radionuclides from the waste glasses. This report presents results of ama1yses of the mucrostructures of glasses made with actual waste sudges from two SRP waste tanks. X-ray analyses of the glasses and differemtial themal analyses (DTA) of glasses containing simulated sludges are also presented.

The power density of aged SRP waste sludge is low (20.001 $W / g)$, and the $\$$ torage temperature of glass waste forms is expected to be much less than the temperature at which devitrification occurs $\left(0600^{\circ} \mathrm{C}\right)$.

mis work included a study of the compatibility of SRP waste with glass and analyses of devitrification products that would be formed under unusual conditions.

TABLE

Composition of Gass Frit (Giass Mix 18)

\begin{tabular}{|c|c|}
\hline Componers & 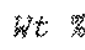 \\
\hline $\mathrm{SHO}_{2}$ & 52.5 \\
\hline $\mathrm{Na}_{2} \mathrm{O}$ & 22.5 \\
\hline $\mathrm{B}_{2} \mathrm{O}_{3}$ & 10.0 \\
\hline $\mathrm{roO}_{2}$ & 10.0 \\
\hline $\mathrm{CaO}$ & 5.0 \\
\hline
\end{tabular}




\section{DESCRIPTION OF SRP WASTE}

At sap, high-level waste is presently stored in underground tanks. The waste consists of an alkaline salt solution, a solid sat cake, and an insoluble sludge layer that contains iron, aluminum, manganese, uranium, and many othex elenents. In the conceptual process for solidification, the waste for longer-tem storage would be removed from a tank by dissolving the salt cake with water and sluicing the slurry of sludge and solution from the tank. Sludge and solution would be separated by centrifugam tion and filtration. Cesium-137, the principal biological hazard in solution, would be removed by an ion exchange process and sorption on zeolite. Sludge would be washed to remove salts, dried, and blexded with the cesium-zeolite for solidification into either concrete or glass.

Approximately 25 liters (total) of sludge, varying in age from 3 to 6.5 yeaxs, was collected from 3 SRp waste tanks (Tanks 5,13 , and 15). The sludge was washed to remove soluble salts and then dried to obtain a free-flowing powder. Details of suluge collection and processing are discussed elsewhere. Table 2 shows only majox elements of the chemical composition of the three sludges, which vary widely in composition. Tank 5 is rich in uranium, and Tank 15 contains mainly $\mathrm{Al}_{2} \mathrm{O}_{3}$. Table 3 shows the radionetric composition of the sludge. The principal radionuclide component is ${ }^{90} \mathrm{Sr}$, although ${ }^{14} \mathrm{Ce}$ is present in a substantial amount.

TABLE 2

Chemical Composition of Washed, Dried Sludges

\begin{tabular}{|c|c|c|c|}
\hline wemert & $\begin{array}{l}\text { Tank : } \\
\text { wty (mote }\end{array}$ & $\begin{array}{l}\text { Tank } 23 \\
\text { wto (mole } \%)\end{array}$ & $\begin{array}{l}\text { mank } 15 \\
\text { wt } \\
\text { s mole }\end{array}$ \\
\hline Fe & $27.5(39.6)$ & $27.9 \quad(39.9)$ & $3.1 \quad(3.9)$ \\
\hline $\mathrm{Mn}$ & $10.8\langle 15.9\}$ & $8.8(12.8)$ & $2.3(2.9)$ \\
\hline Al & $1.5(4.6)$ & $7.3(21.0)$ & $33.5(86.2)$ \\
\hline u & $15.4(5.2)$ & $4.0(1.3)$ & $0.9(0.3)$ \\
\hline wa & $6.1(21.6)$ & $3.1(10.7)$ & $1.2(3.6)$ \\
\hline $\mathrm{ca}$ & $0.6(1.3)$ & $2.3(4.7)$ & $0.2(0.4)$ \\
\hline 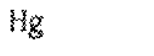 & $0.1(-)$ & $2.1(0.8)$ & $0.9(0.3)$ \\
\hline$N i$ & $5.1(7.1)$ & $0.5\{0.7\}$ & $0.5(0.6)$ \\
\hline
\end{tabular}

a. Major lements only. 
TABLE 3

Radionuclides in Washed, Dried Sludges

\begin{tabular}{|c|c|c|c|}
\hline & कonk 6 & wank 33 & $3 a n k 25$ \\
\hline $85 x$ & 74.7 & 15.5 & 25.6 \\
\hline${ }^{3} b_{4} \mathrm{Ce}_{0}$ & 4.8 & 2.0 & 16.9 \\
\hline$x e^{2}$ & 2.7 & 0.4 & 1.7 \\
\hline 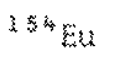 & 0.5 & 0.3 & 1.2 \\
\hline $137 \mathrm{Cs}$ & 2,3 & 0.3 & 0.1 \\
\hline 12583 & 0.4 & 0.1 & 1.5 \\
\hline Gross a & 0.1 & 0.3 & 0.1 \\
\hline
\end{tabular}

\section{GLASSES CONTAINING ACTUAL SRP SLUDGE ${ }^{2}$}

Chasses were made with the glass frit (Glass Mix 18) and the actual sludges. When this glass was heated to $1150^{\circ} \mathrm{C}$, 40 wt of exther Tank 5 or Tank 13 sludges could be incorporated into good waste forms. Whth Tank 15 sludge, which is rich in aluminum, a glass containing ony 25 wt sludge could be vitrified. In one test, 30 wt than 13 sludge and 10 wt cesiummeolite were vitrified. In all of the tests, the glasses were melted at $1150^{\circ} \mathrm{C}$ for 3 hours ${ }^{2}$ alumina crucibles. The molten glasses were then poured into graphte molds and annealed at $500^{\circ} \mathrm{C}$ for 1 hour. Dux inc melting, approximately 3 : of the ${ }^{105} \mathrm{Ru}, 0.3 \%$ of the ${ }^{13}{ }^{7} \mathrm{Cs}$, and al of the mercury volatidized.

Some of the product glasses wexe leached in stagnant, distilled watew at arbient temperature, and the leachabilities determ mined as previous $y$ described. ${ }^{2}$ other glasses were heated for 1 month at either $500^{\circ} \mathrm{C}$ or $600^{\circ} \mathrm{C}$, and then leached as before. Eoth asmeast and herted glasses were also immersed in boiling water to accelerate leaching and define the relative solubilities of the phases present.

Since the sludge collected fron Tank 15 was probably not representative of the entire tank contents, no heating tests or matcrostructural analyses were made on glass containing this sludge. 


\section{RESULTS OF LEACH TESTS}

Leachabilities of the glasses at ambient temperatures, based on the entire leach period of 84 to 100 days, are shown in Table 4. theating the glasses at $500^{\circ} \mathrm{C}$ or $600^{\circ} \mathrm{C}$ increased the ${ }^{9} \mathrm{Sr}$ leachablitity by approximately a factor of 10 ; however, the final product still had a leachability of $40^{-6} \mathrm{~g} /\left(\mathrm{cm}^{2}\right)(\mathrm{day})$, which is considered low for waste forms.

Heating Glasses $18-40-5$ and $18-30-13 / \mathrm{Z}^{*}$ at $500^{\circ} \mathrm{C}$ did not significantly affect the ${ }^{137} \mathrm{Cs}$ leachability. However, heating Glass $18-40-13$ at $600^{\circ} \mathrm{C}$ increased the ${ }^{137} \mathrm{Cs}$ leachability by a factor of 100 [fron $10^{-8}$ to $10^{-6} \mathrm{~g} /\left(\mathrm{cm}^{2}\right)$ (day)] probably because of devitrification. Glass $18-40-5$, having the same treatment, increased in ${ }^{13} \mathrm{Cs}$ leachability by only a factor of 2 [from $6 \times 10^{-6}$ to $1 \times 10^{-7} \mathrm{~g} /\left(\mathrm{cm}^{2}\right)$ (day) $]$. Heating at $500^{\circ} \mathrm{C}$ and $600^{\circ} \mathrm{C}$ did not afect leachability of alpha activity.

TABLE 4

Comparison of Leachabillities of heated and Unheated Waste Glasses

Somptes

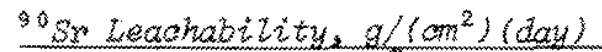

$18 \cdots 40 \cdots 5$

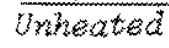
$500^{\circ} \mathrm{C}$ $600^{2} \mathrm{C}^{2}$

$18-40+13$

$$
2.2 \times 10^{-7}
$$

$7.0 \times 10^{-6}$ $5.0 \times 10^{-6}$

$38-30-13 / 2$ $4.4 \times 10^{-7}$

$6.4 \times 10^{-6}$ $4.3 \times 10^{-5}$$$
1.2 \times 10^{7}
$$$$
2.2 \times 10^{-6}
$$

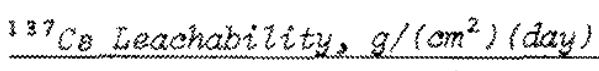

$18-40-5$

$$
5.9 \times 10^{-3}
$$

$3.7 \times 10^{-8}$

$$
1.0 \times 10^{-7}
$$

$18+40-13$

$3.5 \times 10^{-3}$

$3.1 \times 10^{-7}$

$18-40 \sim 13$ $1.3 \times 10^{-7}$ $6.0 \times 10^{-8}$ $2.7 \times 10^{-7}$

$18-30-33 / 2$

$$
-
$$$$
6.1 \times 10^{-8}
$$

a. Heated 1 month.

* 18 is Glass $\mathrm{m}$ (x) number: 30 is wt sludge; $z$ signifies 10 wt gesium-zeolite. 


\section{GLASSES CONTAINING SIMULATED SLUDGES}

Classes containing 35 wt: Tank 5 and Tank 13 simulated sludges, and $25 \mathrm{kt}$ thank 15 simulated sludge were prepared by the comique described above. These glasses were analyzed by Wifferential Thermal Analysis (OTA) to detemine the temperature of maxim crystat growth (temperature of maximum devitrification wate). The glass containing Takk 13 simulated sludge devitrified with maximum rate of crystallization at $610^{\circ} \mathrm{C}$. Glasses containing anulated Tank $\$$ and Tank 15 sludges did not devitrify on heathry to $9900^{\circ} \mathrm{C}$. These results corroborate the leach test rem sults whin indicated that the $600^{\circ} \mathrm{C}$ heat treatment of Glass $18-40$ m 3 caused devitrification.

To facilitate interpretation of leach-test results and identification of precipitated phases, a similar glass sample was cast containing $35 \mathrm{wt}$ simulated Tank 13 sludge and 1 wt of cestum and strontium. The microstructure of the glass was examined by optical and scanning electron microscopy, and the clemental compositions of the precipitates were determined by both maroprobe and energy-dispersive $x$-ray analyses. As with samples containing actual sludge, this simulated sludge-glass matrix contained uniform distribution of dendritic particles; this shape indicates that they precipitated from the melt during cooling. These particles contained principally iron with some mangarese, nickel, and titanium. The concentrations of cesium and strontim were not measurably different in both precipitate and matrix; there was no obvious preferential segregation. When the sample was leached in boiling water, the glass matrix was attacked preferentially. These results suggest that the precipitates are possibly beneficial in that some of the cesium and strontium are contained in a less-1eachable form (precipitates).

\section{MICROSTRUTURES OF GLASSES CONTANUNG ACTUAL SLUDGES}

Six gyss samples, three that were heated and three asmcast, were cambed by optical microscopy. Glass 18-40-13 consisted of a matrix fin which particles and clusters of particles were distributed unifomly (figure 1a). Although these particles were not analyzed, they probably contained iron, manganese, nickel, and titanium, as was found in particles of similar appearance in glass containing $35 \mathrm{wt}$ simulated sludge. Heating at $600^{\circ} \mathrm{C}$ for month devitufied the glass matrix, as evidenced by the formam tor of small crystallites (Figure lb). During leaching for 96 hours in boiling water, the glass matrix leached faster than the particles in both the as-cast and devitrified glasses. The shape of holes that developed in the devitrified glass during leaching suggests that leaching occurred along crystallite boundaries (Figure $1 \mathrm{c}$ ). 


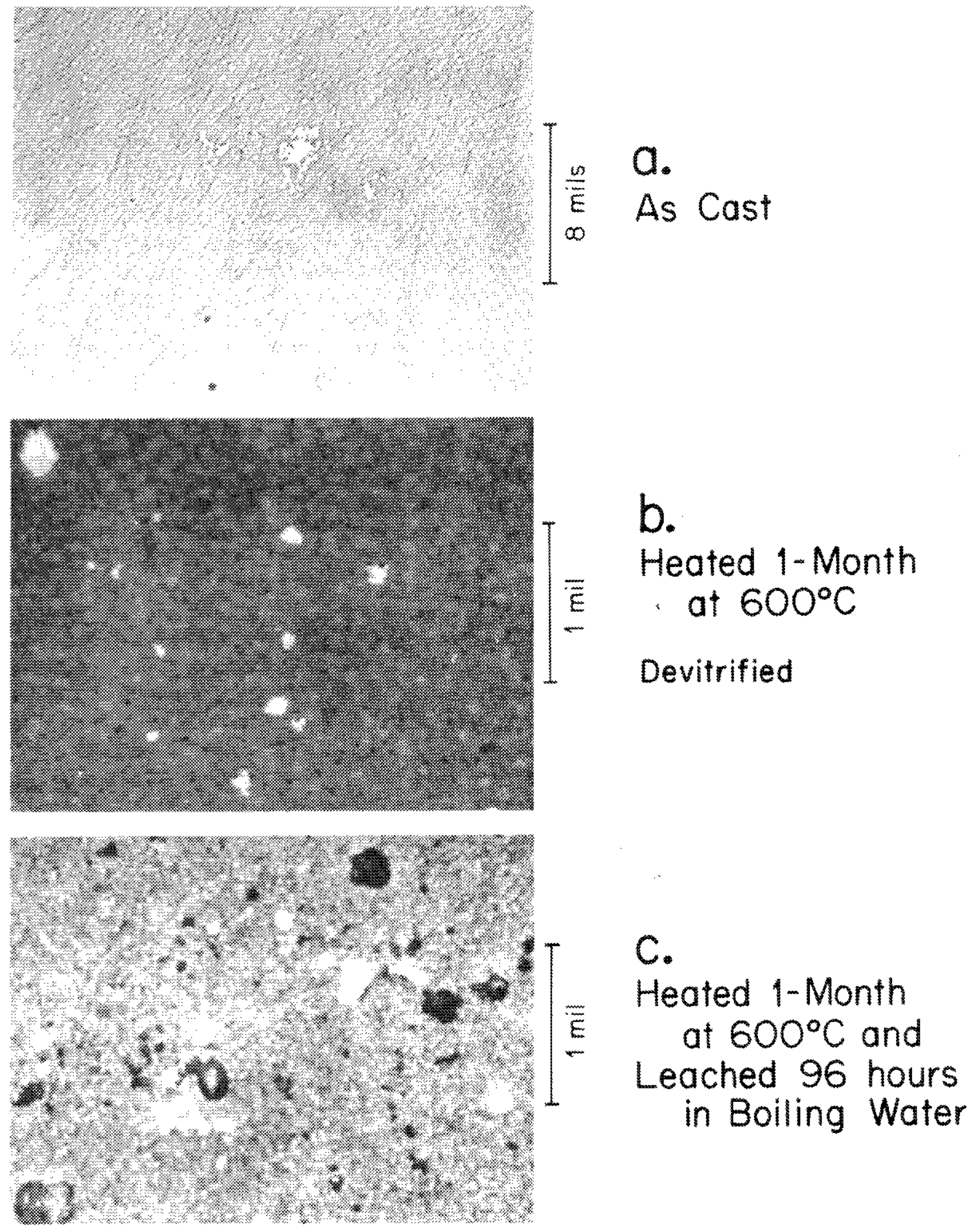

FIGURE 1. Microstructure of Glass 18-40-13 
The microstructure of Glass $18-40-5$ (Figure 2a) was similax to that of the glass containing Tank 13 sludge except that the rank 5 glass contaned many more precipitated particles, in agreenent with the higher total of iron, manganese, and nickel in this sludge (Table 2). Heating for 1 month at $600^{\circ} \mathrm{C}$ did not appear to devitricty the glass matrix. In both as-cast and heated Tank 5 glasses, the glass matrix was attacked more rapidly than the particles, and no holes formed duxing leaching; the ${ }^{13}$ "Cs leachabilicy of the heated rank 5 glasses measured at $25^{\circ} \mathrm{C}$ was similax to that of the unheated glass.

No particles prectpitated in Glass $18-30-13 / 2$ (Figure 3 a). The absence of particles indicates that the solubility limit for the metallic constituents (iron, manganese, and nickel) is between 30 and $35 \mathrm{wt} \%$. Heating for 1 month at $500^{\circ} \mathrm{C}$ had no effect on microstucure or ${ }^{3}{ }^{7} \mathrm{Cs}$ leachability. Undissolved zeolite particles were found occasionally (Figure $3 \mathrm{c}$ ), but these could probably have beer eliminated simply by heating longer than 3 hours at the melting temperature $\left(1150^{\circ} \mathrm{C}\right)$.

\section{X-RAY ANALYSES OF GLASSES CONTAINING ACTUAL SLUDGES}

Four glasses containing actual SRP sludges from Tanks 5 and 13 were analyzed by wide-angle x-ray diffxaction. Two of the glasses were asmcast, and two had been heated for 1 month at $600^{\circ} \mathrm{C}$.

Giasses $18-40-5$ and $18-40-13$ as - cast contained both crystalline and anomphous phases. The main crystalline component in both glasses was $\gamma \mathrm{Fe}_{2} \mathrm{O}_{3}$, with an expanded lattice parameter, probably resulting from manganese, nickel, and titanium in solution. G1as 18-40-5 had nore $\gamma-$ Fe $_{2} 0_{3}$ in its matrix than had G1ass 18-40-13; this was also shown by metallographic examination. Heating Glass $18-40 m 5$ at $600^{\circ} \mathrm{C}$ cor 1 month did not cause devitrification, con-

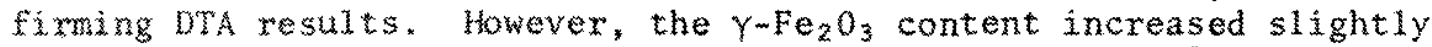
during the heat treatment. Heating Glass $18-40 \mathrm{~m} 13$ at $600^{\circ} \mathrm{C}$ did cause devitrification, as expected from the DTA and leach test results. The major crystalline phase formed was nepheline, NaAlsio along with some Cay Fey $\mathrm{O}_{25 .}$. Nepheline was also the major crystalline phase in devitrifod glass containing simulated sludge. 


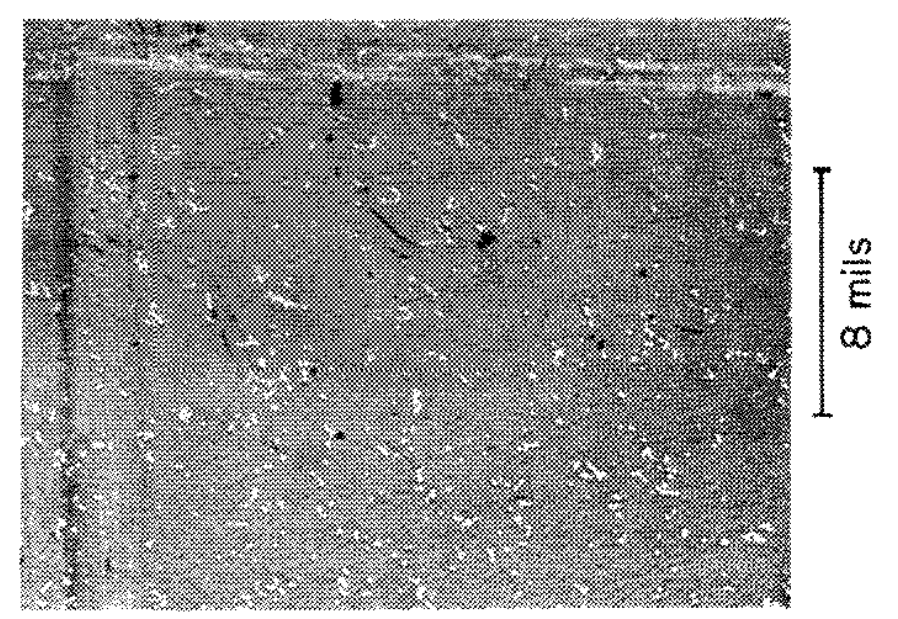

\section{a. \\ As Cast}

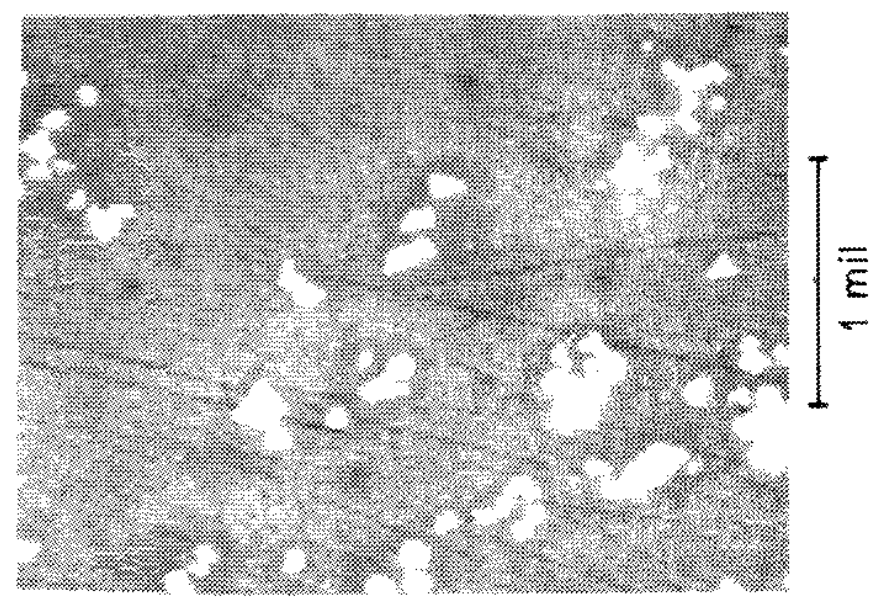

b.

Heated 1-Month at $600^{\circ} \mathrm{C}$

Not Devitrified

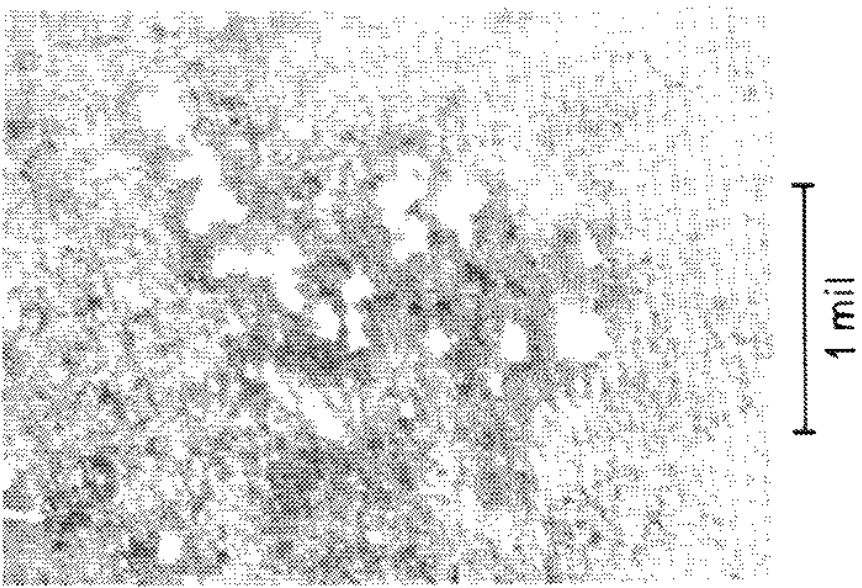

c.

Heated 1-Month at $600^{\circ} \mathrm{C}$ and Leached 96 hours in Boiling Water

FIGURE 2. Microstructure of Glass 18-40-5 


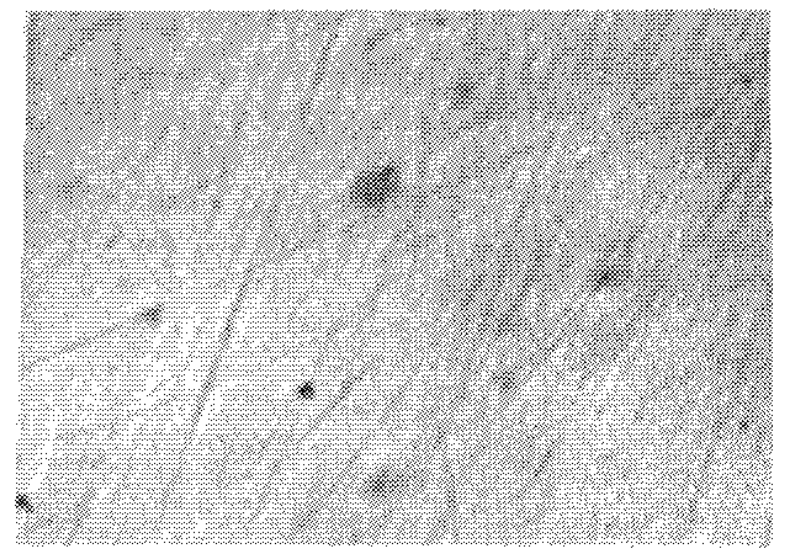

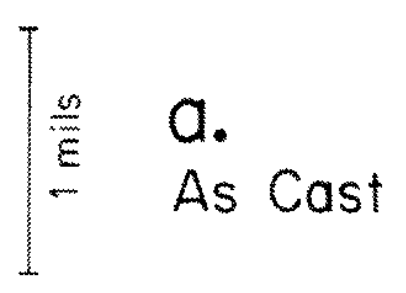

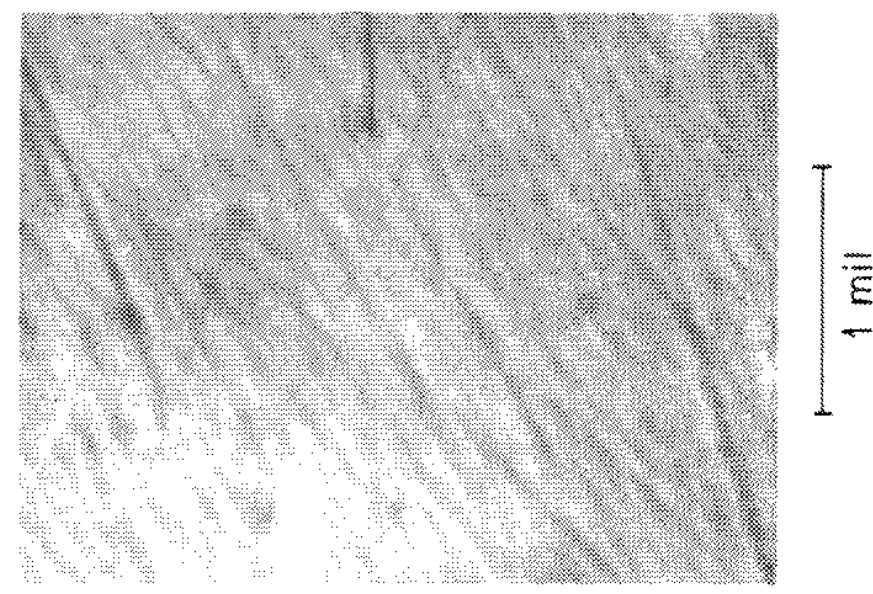

b.

Heated 1-Month at $500^{\circ} \mathrm{C}$

Not Devitrified

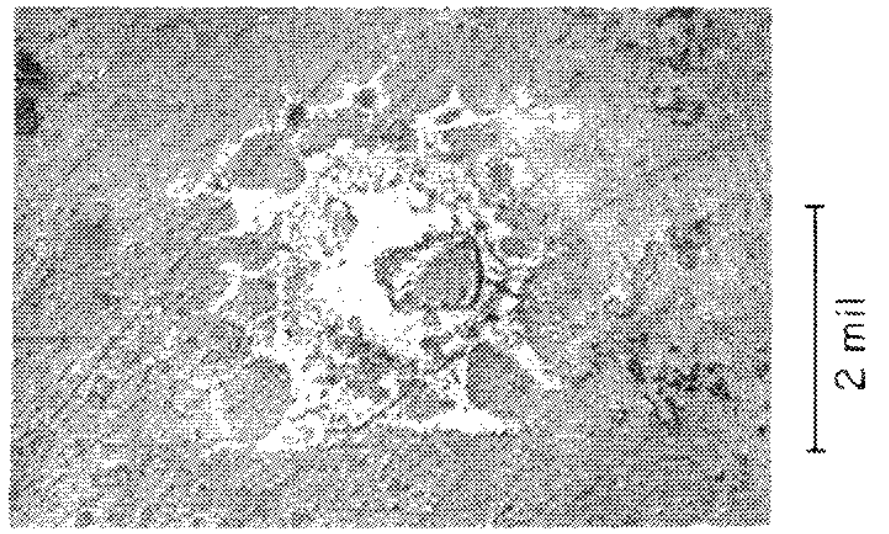

C.

Heated 1-Month at $500^{\circ} \mathrm{C}$ and Leached 96 hours in Boiling Water

FIGURE 3. Microstructure of Glass $18-30-13 / 2$ 
CONCLUSTOWS AND FUTURE WORK

Whis work showed that good glasses can be made with SRP waste sludges. All sludge components, except mercury which is volatilized, can be solubilized in a relatively lowmelting gass. Small amounts of crystalline $\gamma-\mathrm{Fe}_{2} \mathrm{O}_{3}$, containing some sludge components in solution, precipitate in the glass during cooling from the melt. These precipitates have no adverse effucts: their leachabilities are less than those of their glass matrices and they are not enriched in cesium and strontium. The glass containing 40 wt "Tank 13 sludge devitrified when heated at $600^{\circ} \mathrm{C}$ for 1 month, as shown by DTA, $\mathrm{x}-\mathrm{xay}$, and microscopic analyses. Devitrification increased the ${ }^{137} \mathrm{Cs}$ leachability by a factor of approximately 100. The glass containing 40 wt Tark 5 sludge did not devitrify with the same heat treatment even though the two sludges have similar chemical compositions.

Further woxk will be directed toward understanding why Tank 5 glass does not devitrify and Tank 13 glass does. Also, gusses containing sludges from other SRP waste tanks will be made in 304l stainless steel tubes to investigate in can melting of SRP waste sludges. Glass products wil be leached and analyzed moroscopically and by $x$-ray diferaction. 


\section{REFERECWS}

1. 3. A. Kelley. Soltuation of Glass as a Matrix fox solidim fiuation of Savannah Rivex plant Waste. Nonxadioactive and Trocer Studies. USEWDA Report DP.1382, E. I. du pont de Nemours and Co. Savamah River Laboratory, Aiken, SC (1975).

2. I. A. Nelley. Evaluation of Glass as a Matrix for solidificatron of Savamah River piant Waste. Radioactive Studies. USERBA Repoxt DP-1397, E. I. du Pont de Nemours and Co., Savannah Ruer Laboratory, Alken, SC (1975). 